\title{
R U There? Ostracism by Cell Phone Text Messages
}

\author{
Anita Smith \\ Macquarie University
}

\author{
Kipling D. Williams \\ Purdue University
}

\begin{abstract}
Ostracism has a powerful negative effect on individuals. Face-to-face (i.e., social) ostracism is not necessary for these effects to emerge; they occur also in Internet ball toss games and within chat rooms. In previous research, ostracized individuals observed the interaction between other members of a group. In this experiment, the authors tested whether imagined ostracism is sufficient to inflict psychological pain. They used a triadic cell phone text-messaging method such that after initial inclusion in a conversation, participants either continued to be included or received no further messages from the others (and saw no messages between the others). Ostracized participants reported worse mood; reported lower state levels of belonging, control, self-esteem, and meaningful existence; and wrote more provoking messages.
\end{abstract}

Considerable research in the areas of ostracism (i.e., being ignored and excluded; Eisenberger, Lieberman, \& Williams, 2003; Williams, 2001; Williams, Cheung, \& Choi, 2000; Zadro, Williams, \& Richardson, 2004), social exclusion (Twenge, Baumeister, Tice, \& Stucke, 2001; Twenge \& Campbell, 2003; Twenge, Catanese, \& Baumeister, 2003), and rejection (Leary, 1990, 2001; Leary, Kowalski, Smith, \& Phillips, 2003) has demonstrated that being ignored, excluded, or rejected is a uniformly unpleasant, even painful (Eisenberger et al., 2003) experience. According to Leary's sociometer hypothesis (Leary \& Baumeister, 2000; Leary, Tambor, Terdal, \& Downs, 1995), these aversive interpersonal events signal relational devaluation, which results in hurt feelings and lowered levels of belonging and self-esteem. According to Baumeister and Leary's

Anita Smith, Department of Psychology, Macquarie University, Sydney, New South Wales, Australia; Kipling D. Williams, Department of Psychological Sciences, Purdue University.

An earlier version of this article was presented at the meeting of the Society for Australasian Social Psychologists, Sydney, New South Wales, Australia, April 2003. We thank the Australian Research Council for funding Kipling D. Williams for this research. We are indebted to Hausmann Communications, who supplied three Nokia mobile phones for this research. Thanks also go to Geoff MacDonald for his comments on a draft.

Correspondence concerning this article should be addressed to Kipling D. Williams, Department of Psychological Sciences, Purdue University, West Lafayette, IN 47907. E-mail: kip@psych.purdue.edu
(1995) belongingness theory, social exclusion causes anxiety because it signals a potential or actual loss of belonging. And according to Williams's $(1997,2001)$ need-threat model of ostracism, being ignored and excluded can simultaneously thwart desires of belonging, self-esteem, control, and meaningful existence.

The research on ostracism, for example, has demonstrated that simply being ignored and excluded is enough to produce lower self-reported satisfaction levels of belonging, control, selfesteem, and meaningful existence regardless of how irrational this reaction is. For instance, Eisenberger et al. (2003) found that participants ostracized in a virtual ball toss game, Cyberball (Williams et al., 2000), reported lower levels on these needs even when they were told that their computer was not yet hooked up to the other two people's computers; thus, the others could not throw the ball to them even if they wanted to. Zadro et al. (2004) found that being ostracized on Cyberball by the computer was just as unpleasant as being ostracized by other human beings. And more recently, Gonsalkorale and Williams (2004) found that Cyberball participants were just as negatively affected when they were ostracized by in-group members (of the same political party), out-group members (of the rival political party), or even despised outgroup members (the Ku Klux Klan). Clearly, the research indicates that being ostracized sets off pain signals to the brain (as shown in functional magnetic resonance imaging [fMRI] brain scans by Eisenberger et al., 2003) to pre- 
pare the individual to deal immediately with the threat of exclusion, and that this sequence of events is so powerful that it appears to occur precognitively. That is, cognitive factors that ought to diminish the negative impact of ostracism (nondeliberate, by hated out-groups or computers) do not.

To date, research on these variously connected concepts has been conducted in face-toface settings, in chat rooms, or through the use of Cyberball (for reviews, see Leary, in press; Twenge, in press; Williams \& Zadro, in press). The one common element in all of these paradigms is that participants are excluded, ignored, or rejected while they see or hear the others in the group engaging in social intercourse. Thus, it is not clear whether being ignored and excluded is sufficient to cause the negative feelings or whether being ignored and excluded must be coupled with seeing or knowing that the others in the group are enjoying social inclusion with each other. One purpose of the present study was to devise a paradigm in which the ignored and excluded participant does not see or hear the others engaging in social interaction to determine whether ostracism alone is sufficient to thwart the desired needs postulated by Williams $(1997,2001)$. One relatively new method of social communication, the cell phone, offers such a paradigm.

The invention of the cell phone has had a profound effect on the way in which people communicate and organize their lives (Geser, 2002). Cell phones have made it easier for people to communicate both in verbal and in written form by way of cell phone text message communication, otherwise known as SMS (short message service). The development of SMS communication has surpassed all expectations (Rautiainen \& Kasesniemi, 2000). According to Vodafone, in the year 2000 the number of messages sent jumped fivefold, to 200 billion messages, and in 2002 the number of text messages rose to 366 billion. In the year 2000 a Danish medical clinic admitted its first text-messaging addict, who sent up to 200 messages a day (Underhill et al., 2001).

New technologies such as text messaging are making it easier for people to maintain contact. However, these technologies bring with them new means to perpetrate existing social problems such as harassment and relational aggression. In contrast to physical aggression, rela- tional aggression involves harming a person psychologically by manipulating relationships or threatening to hurt a person or that person's property (Crick, Casa, \& Nelson, 2002). A survey conducted by the National Children's Home found that $16 \%$ of children between the ages of 11 and 19 were harassed by text messaging, whereas only $7 \%$ were harassed in Internet chat rooms and $4 \%$ were harassed via e-mail. In Scotland and New Zealand, text message bullying has become such a problem that some schools have banned mobile phones ("Text message bullies," 2001; "Text message bullying," 2001). However, it is not only school children that are taking advantage of the latest way to terrorize others. After a horrific gang rape in Sydney, Australia in 2002, one of the perpetrators sent disturbing text messages to his victims, and when his phone was seized, messages such as "When you are feeling down ... bash a Christian or Catholic to lift up" were found stored on his phone (Wockner, 2002, p. 3).

There is evidence that text message communication can have a profound effect on an individual's emotions (Taylor \& Harper, 2003). In severe cases of text message harassment, aggressive text message campaigns have apparently contributed to suicide attempts. Gail Jones, aged 15, took an overdose of drugs after receiving a series of aversive text messages and silent calls (McVeigh, 2001).

According to Crick et al. (2002), a common approach of perpetrators of relational aggression is to threaten withdrawal of affection or to exclude their target from important social gatherings. Taylor and Harper (2003) found that if an individual did not receive the text messages they expected, this breached underlying agreements between friends and left the individual feeling excluded from social networks. There is qualitative evidence that individuals who do not receive text messages when they expect to feel left out and dejected (Taylor \& Harper, 2003). However, so far this issue has not been empirically addressed. One aim of this study was to examine whether short episodes of text message ostracism lead to feelings of being ignored and excluded. If they do, the individuals are expected to suffer a cascade of negative effects. 


\section{Ostracism}

The predictions made in this study are based on the theoretical predictions derived from Williams's (2001) model of ostracism. The crux of the theory proposes that ostracism has the unique potential to threaten state levels of four fundamental human needs: belonging, control, self-esteem, and meaningful existence. When ostracized, the individual perceives a severing of the bond between him- or herself and the others, is frustrated by having no control over eliciting a response, assumes that he or she has done something wrong or bad to deserve such treatment, and has the unusual experience of feeling nonexistent. Each of these needs has received extensive attention in the psychology literature as being fundamental to human motivation and well-being (e.g., Baumeister \& Leary, 1995, for belonging; Seligman, 1975, for control; Tesser, 1988, for self-esteem; and Greenberg et al., 1992, for meaningful existence). Consistent with the literatures on the four needs, the model predicts that targets of ostracism will attempt to cope with the thwarted needs by trying to refortify them. For example, when targets' belonging is threatened, they may attempt to strengthen bonds with other individuals or groups.

Williams and Sommer (1997) first examined ostracism with a triadic ball toss paradigm in which half of the participants were not thrown the ball after the first initial set of throws (for other studies using this paradigm, see Williams, 2001). The impact of ostracism is so immediate and powerful that the social presence of the ostracizers is unnecessary. Subsequently, it was shown that mood and state need levels would suffer even when individuals were ostracized by the computer ball toss paradigm Cyberball. ${ }^{1}$ In this game, participants are led to believe that they are simply engaging in an exercise that will increase their mental visualization skills. Convinced that they are playing a game of Internet ball toss with two others (whom they do not know, see, or expect future meetings with), half are included in the game whereas the other half are ostracized after having been thrown the ball once. Williams, Cheung, and Choi (2000) found that Cyberball-ostracized participants reported worse mood and lower state levels of belonging, control, self-esteem, and meaningful existence. They also found an increase in conformity fol- lowing ostracism on a subsequent task (with a new set of people).

To date, the accumulated literature on the immediate effects of ostracism demonstrates that regardless of individual differences in the targets of ostracism and irrespective of the presence of factors that ought to enable the target to discount the importance of the ostracism, ostracism hurts. In fact, despite several attempts, there have been no crosscutting variables that moderate its immediate impact on self-reports of mood or state experiential levels of the four needs. For example, Zadro et al. (2004) showed that participants react just as negatively to $\mathrm{Cy}$ berball ostracism if they are told that they are playing with a computer rather than with other people. What would seem to be easily dismissed as not meaningful is nevertheless painful. Eisenberger et al. (2003) had participants play Cyberball within an MRI chamber and conducted fMRI scans on them during the game. At first, participants were told their computer was not yet linked with the other two people's computers so they were simply to watch the other two people play until their computer was attached. Even with this clearly rational explanation for not being included, participants reported feeling badly (having lower levels of the four needs) and displayed activation in the anterior cingulate cortex (ACC). This activation also occurs when people experience physical pain (Panksepp, 2003). When they were told the computer was attached and they were included, they felt better and showed less ACC activation. Then, when ostracized again (this time the ostracism could be inferred to be intentional), they once again showed higher activation of the ACC. Clearly, it appears that even the slightest hint of ostracism is sufficient to sound a warning alarm in humans, possibly because detection of ostracism has evolved as a mechanism to ward off threats to survival (Panksepp, 2003).

In all of the previous studies on social exclusion and ostracism, it is explicitly clear to the participants that while they are being ostracized, the others continue to engage in interaction with each other (whether it is ball tossing or conversing in a chat room; see Wheaton, 2001; Williams, 2001; Williams et al., 2000; Williams et

\footnotetext{
${ }^{1}$ This program can be freely downloaded from http:// www.psy.mq.edu.au/staff/kip/Announce/Cyberball
} 
al., 2002; Williams \& Sommer, 1997). This type of ostracism is referred to by Williams (1997, 2001) as social ostracism-being ignored and excluded while in the presence of others. Another type of ostracism is physical ostracism, which occurs when the ostracized individual is physically removed from the others, as in time-out disciplinary action in schools, solitary confinement in prisons, or exile from a country. There has been speculation (Williams, 2001) that physical ostracism may not be as painful as social ostracism, because when physically removed, the target is not continuously reminded of being ignored. Immersed in a new environment, the individual can be distracted from being socially outcast from the original group by other stimuli. Furthermore, when individuals are physically ostracized, they are not continuously exposed to the close social interactions between the others in the group. Nevertheless, there are no empirical examinations of physical ostracism.

In the present study, we used cell phone text messaging as a means to achieve a form of physical ostracism. Text messaging works well in this regard because the individual (a) is physically separated from the others and (b) cannot see or hear the continuous interactions between the others. Additionally, because cell phones require technical success for transmission, the individual may be allowed to surmise that his or her ostracism is simply the result of technical difficulties that are affecting all members of the group. Thus, we believed that using cell phone text messaging as the paradigm would provide a more conservative test of the impact of ostracism. Individuals ostracized from text messages do not have to endure the pain associated with being in the presence of others while being ignored and excluded; neither can they be sure that the others are closely interacting with each other. They are also likely aware of the possibility that they (and perhaps the others) are simply experiencing technical difficulties with their phones, and so they may not perceive deliberate ostracism. This paradigm, then, offers ostracized individuals several means by which to dismiss the importance of ostracism and, consequently, to show little negative impact when they are subjected to it.

As in previous investigations, we once again attempted to discover possible moderating factors to the immediate experience of ostracism.
Two such moderating factors were chosen for this study. One involves an individual difference that may be related to how important ostracism is to people's sense of self: individualism-collectivism (Yamaguchi, 1994). Because individuals with collectivistic orientations place more importance on their connection to other people, they may be affected more negatively by ostracism.

Our second factor involves whether participants are interacting with in-group or out-group members. It seems reasonable to expect that being ostracized by in-group members would be more debilitating than being ostracized by outgroup members. It should be easier to dismiss the impact of ostracism by out-group members because one could interpret the ostracism to be based on group membership rather than the result of personal characteristics and shortcomings. In this study, participants' levels of individualism and collectivism were assessed prior to the experimental task, and they were led to believe that during the task they were interacting with two others who were in-group members (i.e., they had similar smoking habits) or out-group members (i.e., they had dissimilar smoking habits).

Consistent with the literature that suggests that even mild forms of ostracism are painful, our primary hypothesis was that despite possible factors that could help participants minimize the impact, participants who were ostracized through cell phone text messaging would report it as a negative experience (characterized by worse mood and lower state levels of needs), compared with the responses of participants who were included. It was also predicted that ostracized participants would attempt to provoke a response from the others when they were left out of the social interaction (see Williams et al., 2002).

\section{Method}

\section{Participants and Design}

Forty-three psychology undergraduates from Macquarie University (27 women and 16 men; mean age $=19.76, S D=2.86)$ were randomly assigned to a 2 (social interaction: ostracism or inclusion) $\times 2$ (group type: in-group or outgroup) between-subjects design. All participants were familiar with text messaging and 
received course credit for their participation. Three participants were excluded from the analyses because they guessed the purpose of the study, resulting in 10 people per condition $(N=40)$.

\section{Procedure}

After the participant and the confederates (one man and one woman) arrived at the laboratory, they were taken to a room where there were three seats arranged in a triangular formation, $60 \mathrm{~cm}$ apart. After providing consent, participants completed a preexperimental questionnaire that assessed demographic and personal habit information and contained items from Yamaguchi's (1994) Collectivism Scale.

Predictor variable. The items from Yamaguchi's Collectivism Scale that were included in the questionnaire were those that received a factor loading greater than .35 in Kashima et al.'s (1995) factor analysis. Seven items measured collectivism, six measured agency, and five measured assertiveness. All three factors are components of collectivism. Participants were asked to circle the number that best described them on a 10-point scale (where $0=$ not at all and $9=$ very much). After the questionnaire was completed, the SMS interaction commenced.

SMS interaction. Participants were told they would be communicating with each other via SMS text messaging because we were interested in the nature of SMS communication. They were told they would begin by answering two questions supplied by the experimenter (one of which constituted the in-group/outgroup manipulation), after which they were to maintain the interaction until the experimenter told them to stop. The two confederates were taken to another room, leaving the participant alone. On the participant's table was a Nokia 3310 cell phone, instructions on how to use the mobile phone, and instructions on what to do in the experiment.

To check that participants knew how to send and retrieve SMSs, we asked them to send the letter "A" to each of the confederates and to retrieve the same message that had been sent to them by the confederate. If the participants could perform this task, the experiment proceeded, with the group responding to two ques- tions, the first a distracter question ("How often do you exercise?").

In-group/out-group manipulation. The second question was used to create the in-group/ out-group manipulation. The group was instructed to send this question: "Do you smoke?" This was also one of the personal habits questions in the preexperimental questionnaire, and so the experimenter told the confederates whether the participant was a smoker or a nonsmoker prior to the in-group/out-group manipulation.

For the in-group condition, the confederates would say that they had the same smoking habits as the participant. For example, if the participant was a smoker, then the confederates would say that they were also smokers. In the out-group condition, the confederates would say they did not share the same smoking habit with the participant: If the participant was a smoker, then the confederates would say that they were nonsmokers. After the participant and the confederates had sent and replied to the specified questions, the group was told to begin their SMS conversation.

Ostracism-inclusion manipulation. Participants were then instructed to compose their own text messages. At this point participants were either ostracized or included for $8 \mathrm{~min}$. If the participant was in the inclusion condition, the confederates continued to interact with the participant for the entire $8 \mathrm{~min}$. Alternatively, if the participant was in the ostracism condition, the confederates responded to none of the participant's messages. In the inclusion condition, the confederates were told to be responsive to the participant's messages, but the participants rarely deviated from the two questions they were asked.

Postexperimental questionnaire. At the conclusion of the SMS conversation, participants were asked to complete a questionnaire, which assessed the four fundamental needs (belonging, control, self-esteem, and meaningful existence), assessed mood (i.e., happy or sad, frustrated, angry, anxious), and contained other questions about their evaluation of the conversation. The questionnaire consisted of self-description items for which they were to respond between 1 (not at all) and 10 (very much). There were 3 questions on each of the four fundamental needs, 10 items measuring affect, 4 items on the participants' experience with the phones, 1 
question measuring the desire for group harmony, and 2 manipulation checks for ostracism-inclusion manipulation (these items have been used in several previous studies, including Williams et al., 2000, and Eisenberger et al., 2003, and are listed verbatim in Zadro et al., 2004). A SIM card reader was used to download the text messages into an Excel file so that they could be content analyzed by the experimenter and one coder, both blind to condition.

After the experiment, the participants were thoroughly debriefed as to the purpose of the study and thanked. Participants were then reintroduced to the confederates and asked to sign a postdebriefing form that gave us permission to use their data (all participants agreed).

\section{Results}

Initially, for each dependent variable, regression analyses were conducted with individualism-collectivism as a continuous variable and group membership and ostracism-inclusion dummy coded. In no analysis did individualism-collectivism yield significant effects, nor did it interact with any other variable. Thus, we excluded individualism-collectivism from the analysis and conducted $2 \times 2$ analyses of variance. Table 1 contains the means and standard deviations of the dependent variables.

\section{Manipulation Checks}

The ostracism-inclusion manipulation was successful. We assessed this manipulation by asking participants to rate themselves from 0 (not at all) to 9 (very much) on these two items: "I was excluded" and "I was ignored." Both items were highly correlated (Cronbach's alpha $=.96)$ and were averaged to form an ostracism index score. Ostracized participants reported feeling more excluded and ignored from the text message communication than included participants, $F(1,36)=116.8, p<.01$.

Participants were actively engaged in the ingroup/out-group manipulation by sending text messages saying whether they were smokers or nonsmokers, and in many instances their conversations continued on this topic. Inspection of their text messages seemed to indicate that participants were fully aware of their group membership status (83\% explicitly mentioned this). For example, one participant wrote that she was ignored "because I responded that I didn't smoke, and they both did. I think that seemed to put up an invisible barrier!"

\section{Belonging, Control, Self-Esteem, and Meaningful Existence}

The self-reported satisfaction levels for the four needs were each assessed by three postexperimental items that asked participants to rate their current feelings from 0 (not at all) to 9 (very much). All of the needs were highly reliable except control. Cronbach's alpha coefficients for each need were as follows: belonging $=.84$; self-esteem $=.83$; meaningful existence $=.81$; control $=.60$. Consequently, each set of items was averaged to form a single index

Table 1

Means (and Standard Deviations) of Variables in the Postexperimental Questionnaire

\begin{tabular}{|c|c|c|c|c|}
\hline \multirow[b]{2}{*}{ Measure } & \multicolumn{2}{|c|}{ Ostracism } & \multicolumn{2}{|c|}{ Inclusion } \\
\hline & $\begin{array}{l}\text { In-group } \\
(n=10)\end{array}$ & $\begin{array}{l}\text { Out-group } \\
(n=10)\end{array}$ & $\begin{array}{l}\text { In-group } \\
(n=10)\end{array}$ & $\begin{array}{c}\text { Out-group } \\
(n=10)\end{array}$ \\
\hline Manipulation check & $7.05(2.19)$ & $6.95(1.75)$ & $1.20(1.35)$ & $0.75(1.73)$ \\
\hline \multicolumn{5}{|l|}{ Fundamental needs } \\
\hline Belonging & $2.83(1.74)$ & $2.97(1.84)$ & $6.87(1.48)$ & $7.23(1.12)$ \\
\hline Control & $2.70(1.17)$ & $3.13(1.18)$ & $5.47(1.92)$ & $5.53(1.94)$ \\
\hline Self-esteem & $3.57(1.53)$ & $3.30(1.53)$ & $5.37(1.86)$ & $5.17(2.01)$ \\
\hline Meaningful existence & $3.53(2.14)$ & $3.10(1.74)$ & $6.83(1.00)$ & $7.77(1.83)$ \\
\hline \multicolumn{5}{|l|}{ Affective measures } \\
\hline Negative mood & $3.45(1.69)$ & $4.73(1.83)$ & $1.43(1.96)$ & $1.38(2.00)$ \\
\hline Anger & $2.25(1.68)$ & $1.95(1.73)$ & $1.08(1.18)$ & $0.68(1.09)$ \\
\hline Group harmony & $5.40(1.71)$ & $5.50(2.59)$ & $3.80(3.12)$ & $3.10(3.48)$ \\
\hline
\end{tabular}

Note. Higher scores indicate that participants reported more of a particular quality. 
for each need. Participants who were ostracized had a lower sense of belonging, $F(1$, 36) $=71.55, p<.01, d=1.61$; control, $F(1$, $36)=26.17, p<.01, d=1.28$; self-esteem, $F(1,36)=11.04, p<.01, d=0.96$; and meaningful existence, $F(1,36)=53.16, p<$ $.01, d=1.51$. No main effects or interactions for group membership emerged.

\section{Affect Measures}

Mood, anger, and desire for group harmony were assessed by the participants' ratings on postexperimental items, with possible scores ranging from 0 (not at all) to 9 (very much). We averaged six items measuring mood (such that high scores indicated negative moods) to form a single mood index (Cronbach's $\alpha=$ .89 ), and the four items on anger were also averaged (Cronbach's $\alpha=.83$ ). Participants answered a single item that asked whether they "wanted things to be more harmonious." Participants who were ostracized reported having a more negative mood, $F(1$, $36)=20.47, p<.01, d=1.17$; were angrier, $F(1,36)=7.13, p<.01, d=0.79$; and wanted more harmony, $F(1,36)=5.08, p<$ $.03, d=0.69$, than those who were included. No significant main effects for group membership or interactions with ostracism were found for these factors.

\section{Content Analysis of Postexperimental Comments}

Only a few participants filled out open-ended questions regarding their attributions for the course of the social interactions, and so statistical analyses were not possible to conduct. Casual observation of the comments suggests personal attributions (i.e., ostracism was done to the person because of something the person him- or herself did; e.g., "Maybe because I responded that I didn't smoke and they both did") were the most common attribution used to explain ostracism $(n=7)$, followed by technical difficulties $(n=5)$, and then blaming the experimenter $(n=3)$. Included participants attributed their treatment to the mobile phones $(n=7)$ or the experimenter $(n=3)$.

\section{Content Analysis of Text Messages}

The text messages were rated by the experimenter and a rater, who were both blind to condition. The interrater reliability was high (Cohen's $\kappa=.93$ ). The categories used to code the messages are shown in Table 2. The most notable finding is that ostracized participants attempted to provoke responses more than did included participants. As shown in Table 3, 12 participants in the ostracism condition typed in text that was coded as provocation, whereas

Table 2

Coding Categories and Descriptions for Text Messages

\begin{tabular}{|c|c|}
\hline Category & Description \\
\hline Provocation & $\begin{array}{l}\text { Any comments that participants may make in an effort to } \\
\text { provoke someone to text message them. For example, "Are } \\
\text { you people not speaking to me. I am being oppressed" and } \\
\text { "How come no } 1 \text { is messaging me?!!" }\end{array}$ \\
\hline Suspicion & $\begin{array}{l}\text { Expressions of suspicion that the aim of the experiment was } \\
\text { different from what participants had been told. For example, } \\
\text { "Is this part of the experiment u guys not msging me back??" }\end{array}$ \\
\hline Boring & $\begin{array}{l}\text { Expressions that participants were finding the experiment boring } \\
\text { For example, "Blah blah! Cmon, getting bored!" }\end{array}$ \\
\hline Smoking & $\begin{array}{l}\text { Any mention the participants make about smoking, beyond what } \\
\text { was specified by the experimenter. For example, "u bOth } \\
\text { smOke except } 4 \text { me!" }\end{array}$ \\
\hline Bad technology & $\begin{array}{l}\text { Any mention the participants make specifically about the } \\
\text { adequacy of the phones and how they are functioning. For } \\
\text { example, "I thought it would make a noise when a msg came } \\
\text { in so i thought it Wasnt working." }\end{array}$ \\
\hline
\end{tabular}


Table 3

Percentages (and Raw Scores) of Categories as a Function of Ostracism-Inclusion

\begin{tabular}{lrrcr}
\hline & \multicolumn{3}{c}{ Categories } \\
\cline { 2 - 5 } Social interaction & Boring & Smoking & Provocation & Bad technology \\
\hline Ostracism $(n=20)$ & $18(3.5)$ & $60(12.0)$ & $60(12.0)$ & $18(3.5)$ \\
Inclusion $(n=20)$ & $2(0.5)$ & $50(10.0)$ & $10(2.0)$ & $8(1.5)$
\end{tabular}

Note. The raw scores represent the number of individuals in a condition who sent one or more text messages in a category.

only 2 were scored as doing this in the inclusion condition.

\section{Discussion}

The primary hypothesis of this study was that individuals who were ostracized from a text message interaction would be adversely affected by the experience. Although considerable research has shown ostracism to be painful, all of the previous studies exposed ostracized participants to the other individuals interacting with each other. It is plausible that an individual's exclusion would be magnified when he or she saw that others continued to enjoy inclusion. We therefore wondered whether the absence of text messages, without explicit knowledge that the others were communicating with each other, would be enough to cause similar painful experiences. The results of our study demonstrate that ostracism from a text message interaction is sufficiently negative to lower selfreported state levels of belonging, control, selfesteem, and meaningful existence and to produce more negative affective ratings.

It is remarkable that text message ostracism was found to be so aversive, considering the following factors. First, the participants did not know the confederates and did not anticipate any further interaction with them. Second, text messages lack nonverbal and paralanguage information that is important when conveying interpersonal and potentially threatening attitudes (Short, Williams, \& Christie, 1976). Third, the participants felt the effects of ostracism even though they had no direct evidence that they were being deliberately ostracized or that the others continued interacting with each other. Yet, not only were the state levels of the four needs significantly lower for those who were ostracized by the text-messaging method, but the effect sizes were large (for most, $d>1.00$ ) and comparable to the effect sizes observed for face-to-face and Cyberball ostracism.

In the text message paradigm, participants were provided with little information to help them make sense of their situation. But the pain associated with ostracism was not alleviated, even for those who did have an explanation for their ostracism (i.e., being the odd person out with respect to smoking habits). As has been shown in other studies (Eisenberger et al., 2003; Zadro et al., 2004), factors that should logically diminish the impact of ostracism have no effect on the immediate experience.

The uncertainty associated with this text message paradigm may actually add to the ostracism effect, rather than subtracting from it. Substantial research has demonstrated that individuals are uncomfortable with uncertainty and are motivated to reduce it (Evans \& Over, 1996; Guerin, 2001; Jetten, Hogg, \& Mullin, 2000; Luck, Hillyard, Mouloua, \& Hawkins, 1996). The ambiguity of the text message situation may contribute to the negative effects of ostracism because of the effort required for ostracized targets to reduce uncertainty. Research by Kramer (1994) suggests that uncertainty can be a culture that breeds paranoid attributions, which could also magnify ostracism's impact in this medium.

There is evidence within this study, as there has been in others, that individuals who are ostracized ruminate over possible explanations for why they are not being included (Williams, 2001). Content analysis revealed that people often blame themselves for the ostracism, even though they have the option of blaming the others or the mobile phones. When people use personal attributions to explain their plight, it magnifies the effects of ostracism (Fenigstein, 
1979; Nezlek, Kowalski, Leary, Blevins, \& Holgate, 1997).

\section{Provocation in Cyberostracism}

This study also supports the contention that targets of cyberostracism (being ostracized through electronic media) display bravado that is not typical in face-to-face (or social) ostracism (Williams, 2001; Williams et al., 2002). This may be because social ostracism is more explicit and awkward than SMS ostracism. Targets of social ostracism sit in the same room as the confederates, and so the ostracism is obviously deliberate and must be endured in the presence of others. However, targets of SMS ostracism (as with e-mail and chat room ostracism) cannot see or hear the confederates, and so they do not have any direct evidence that they are being deliberately ignored. This may lead the target to seek clarification that they are actually being deliberately ostracized, and provocation may be an attempt at achieving this. Cyberostracized participants may also feel bolder because being socially removed from the others reduces a person's inhibitions to confront other people (Short et al., 1976). Seeking clarification and provocation can be used as a means to regain control, which should reduce the negative impact of ostracism (see Warburton, Cairns, \& Williams, 2003).

\section{Group Membership and Individualism- Collectivism Factors}

Individuals who were ostracized by their ingroup were not more adversely affected by ostracism than those who were ostracized by their out-group. Similar findings (or a lack thereof) have occurred in other ostracism research (Gonsalkorale \& Williams, 2004; Williams et al., 2000; Williams et al., 2002). Because in-group/ out-group manipulations are typically quite effective in modifying people's responses to the situation (see Hogg \& Abrams, 2003), we think our results combined with those of the previous studies suggest that reactions to ostracism are so powerful and deep (Brewer, 2003) that it overwhelms factors such as group membership that require more cognitive processing. Additionally, our manipulation of in-group/out-group (smoking habits) was probably more psycho- logically meaningful to university students than manipulations have been in typical minimalgroup paradigms (e.g., being told they prefer Klee or Kandinsky, that they are over- or underestimators, being assigned to the heads or tails group as determined by a coin flip).

Collective and individualistic individuals did not significantly differ in their reactions to ostracism. This finding suggests that one's immediate reaction to ostracism is not moderated by this particular cultural self-construct. Nevertheless, it is premature to form any definitive conclusions. It is possible that collectivism would interact with ostracism if the reactions of those who were extremely and consistently individualistic or collectivistic were compared (Bem \& Allen, 1974). It is also possible that this individual difference may reveal its effects on differential coping responses after a certain period of time elapses. For example, in a recent experiment in which ostracism was manipulated in the Cyberball paradigm, Bowland, Richardson, and Zadro (2003) found that initially, normal and social phobic participants reported similar low levels of the four needs following ostracism compared with those who had been included. After a delay of $45 \mathrm{~min}$, however, the normal sample's self-reported levels were as high as those of included participants, but according to their self-reports, those participants who were high in social phobia had only partially reinstated their need levels.

\section{Summary}

This research breaks new ground by extending the consistent findings that ostracism is painful. It appears that ostracism is painful whether it occurs face-to-face with the relatively rich array of nonverbal communication or in an Internet ball toss game (being played by other people or by the computer, or even when the computer is not attached to the others' computers), where communication of any sort is vastly diminished. This research extends this list to instances in which the ostracized individual cannot see or hear the inclusive behavior of the other group members and must simply deduce that he or she has been excluded. The accumulated evidence points to the conclusion that other potentially mitigating factors, like in-group/out-group membership, individual differences, ability to attribute ostracism to nonpunitive causes, and lack of knowledge that 
others in the group are communicating with each other, are overwhelmed by merely being ignored and excluded. Apparently, the higher level cognitive processes necessary to appreciate why these factors should diminish the importance of ostracism are bypassed when we immediately confront ostracism. Immediate reactions to ostracism, we argue, are precognitive, because humans have evolved to detect even the slightest hint of ostracism and to experience it negatively, to warn that something must be done in order to be reincluded and prevent a threat to survival.

\section{References}

Baumeister, R. F., \& Leary, M. R. (1995). The need to belong: Desire for interpersonal attachments as a fundamental human motivation. Psychological Bulletin, 117, 497-529.

Bem, D. J., \& Allen, A. (1974). On predicting some of the people some of the time: The search for cross-situational consistencies in behavior. Psychological Review, 81, 506-520.

Bowland, C., Richardson, R., \& Zadro, L. (2003). Immediate and delayed effects of ostracism on normals and social phobes. Unpublished manuscript, University of New South Wales, Sydney, Australia.

Brewer, M. B. (2003). Implicit and explicit processes in social judgment: Deep and high. In J. P. Forgas, K. D. Williams, \& W. von Hippel (Eds.), Social judgment: Implicit and explicit processes (pp. 387396). New York: Cambridge University Press.

Crick, N. R., Casa, J. F., \& Nelson, D. A. (2002). Toward a more comprehensive understanding of peer maltreatment: Studies of relationship victimization. Current Directions in Psychological Science, 11, 98-101.

Eisenberger, N. I., Lieberman, M. D., \& Williams, K. D. (2003, October 10). Does rejection hurt? An fMRI study of social exclusion. Science, 302, 290-292.

Evans, J., \& Over, D. E. (1996). Rationality in the selection task: Epistemic utility versus uncertainty reduction. Psychological Review, 103, 356-363.

Fenigstein, A. (1979). Self-consciousness, self-attention, and social interaction. Journal of Personality and Social Psychology, 37, 75-86.

Geser, H. (2002, June). Towards a sociological theory of the mobile phone. Retrieved July 1, 2002, from the Sociology in Switzerland Web site: http:// socio.ch/mobile/t_geser1.htm

Gonsalkorale, K., \& Williams, K. D. (2004, April). The KKK won't let me play: Ostracism by despised outgroups still hurts. Paper presented at the 76th Annual Midwestern Psychological Association Conference, Chicago.
Greenberg, J., Solomon, S., Pyszczynski, T., Rosenblatt, A., Veeder, M., Kirkland, S., \& Lyon, D. (1992). Why do people need self-esteem? Converging evidence that self-esteem serves an anxiety-buffering function. Journal of Personality and Social Psychology, 63, 913-922.

Guerin, B. (2001). Replacing catharsis and uncertainty reduction theories with descriptions of historical and social context. Review of General Psychology, 5, 44-61.

Hogg, M. A., \& Abrams, D. (2003). Intergroup behavior and social identity. In M. A. Hogg \& J. Cooper (Eds.), The Sage handbook of social psychology (pp. 407-431). London: Sage.

Jetten, J., Hogg, M. A., \& Mullin, B. (2000). Ingroup variability and motivation to reduce subjective uncertainty. Group Dynamics: Theory, Research, and Practice, 4, 184-198.

Kashima, Y., Kim, U., Gelfand, M., Yamaguchi, S., Choi, S., Yuki, M., et al. (1995). Culture, gender, and self: A perspective from individualism-collectivism research. Journal of Personality and Social Psychology, 69, 925-937.

Kramer, R. M. (1994). The sinister attribution error: Paranoid cognition and collective distrust in groups and organizations. Motivation and Emotion, 53, 199-229.

Leary, M. R. (1990). Responses to social exclusion: Social anxiety, jealousy, loneliness, depression, and low self-esteem. Journal of Social and Clinical Psychology, 9, 221-229.

Leary, M. R. (2001). Toward a conceptualization of interpersonal rejection. In M. R. Leary (Ed.), Interpersonal rejection (pp. 3-20). New York: Oxford University Press.

Leary, M. R. (in press). Varieties of interpersonal rejection. In K. D. Williams, J. P. Forgas, \& W. von Hippel (Eds.), The social outcast: Effects of ostracism, social exclusion, rejection, and bullying. New York: Psychology Press.

Leary, M. R., \& Baumeister, R. F. (2000). The nature and function of self-esteem: Sociometer theory. In M. P. Zanna (Ed.), Advances in experimental social psychology (Vol. 32, pp. 1-62). San Diego, CA: Academic Press.

Leary, M. R., Kowalski, R. M., Smith, L., \& Phillips, S. (2003). Teasing, rejection, and violence: Case studies of the school shootings. Aggressive Behavior, 29, 202-214.

Leary, M. R., Tambor, E. S., Terdal, S. K., \& Downs, D. L. (1995). Self-esteem as an interpersonal monitor: The sociometer hypothesis. Journal of Personality and Social Psychology, 68, 518-530.

Luck, S. J., Hillyard, S. A., Mouloua, M., \& Hawkins, H. L. (1996). Mechanisms of visual-spatial attention: Resource allocation or uncertainty reduction? Journal of Experimental Psychology: Human Perception and Performance, 22, 725-737. 
McVeigh, T. (2001, January 8). Bullies prey on half of all children. Retrieved May 2, 2002, from http:// society.guardian.co.uk/socialcare/news/0,8372, 419274,00.html

Nezlek, J. B., Kowalski, R. M., Leary, M. R., Blevins, T., \& Holgate, S. (1997). Personality moderators of reactions to interpersonal rejection: Depression and trait self-esteem. Personality and Social Psychology Bulletin, 23, 1235-1244.

Panksepp, J. (2003, October 10). Feeling the pain of social loss. Science, 302, 237-239.

Rautiainen, P., \& Kasesniemi, E. (2000). Mobile communication of children and teenagers: Case Finland 1997-2000. Retrieved July 1, 2002, from the Sociology in Switzerland Web site: http://www. telenor.no/fou/prosjekter/Fremtidens_Brukere/ seminarer/mobilpresentasjoner/Proceedings\%20_ FoU\%20notat_.pdf

Seligman, M. E. P. (1975). Helplessness: On depression, development, and death. San Francisco: Freeman.

Short, J., Williams, E., \& Christie, B. (1976). The social psychology of telecommunications. London: Wiley.

Taylor, A. S., \& Harper, R. (2003). The gift of the gab: A design oriented sociology of young people's use of mobiles. Journal of Computer Supported Cooperative Work (CSCW), 12, 267-296.

Tesser, A. (1988). Toward a self-evaluation model of social behavior. In L. Berkowitz (Ed.), Advances in experimental social psychology (Vol. 21, pp. 181-227). San Diego, CA: Academic Press.

Text message bullies action call. (2001, March 16). Retrieved May 9, 2002, from the BBC News Web site: http://news.bbc.co.uk/hi/english/uk/scotland/ newsid_1225000/1225223.stm

Text message bullying 'suited to girls.' (2001, April 11). Retrieved May 2, 2002, from http://www. ananova.com/news/story/sm_236060.html?menu= news.technology

Twenge, J. M. (in press). When does social rejection lead to aggression? The influences of situations, narcissism, emotion, and replenishing connections. In K. D. Williams, J. P. Forgas, \& W. von Hippel (Eds.), The social outcast: Effects of ostracism, social exclusion, rejection, and bullying. New York: Psychology Press.

Twenge, J. M., Baumeister, R. F., Tice, D. M., \& Stucke, T. S. (2001). If you can't join them, beat them: Effects of social exclusion on aggressive behavior. Journal of Personality and Social Psychology, 81, 1058-1069.

Twenge, J. M., \& Campbell, W. K. (2003). "Isn't it fun to get the respect that we're going to deserve?" Narcissism, social rejection, and aggression. Personality and Social Psychology Bulletin, 29, 261-272.

Twenge, J. M., Catanese, K. R., \& Baumeister, R. F. (2003). Social exclusion and the deconstructed state: Time perception, meaninglessness, lethargy, lack of emotion, and self-awareness. Journal of Personality and Social Psychology, 85, 409-423. Underhill, W., Theil, S., Chiou, F., Itori, K., Nadeau, B., Ferro, C., \& Vitug, M. (2001, April 26). The text generation (short message service). Newsweek International, Article A72519301. Retrieved July 3, 2002, from http://80-web5.infotrac.galegroup .com.simsrad.net.ocs.mq.edu.au/itw/infomark/ 0/1/1/purl=rc6_EAIM?sw_aep=Macquarie

Warburton, W., Cairns, D., \& Williams, K. D. (2003, April). Effects of ostracism and loss of control on aggression. Paper presented at the 32nd Annual Meeting of the Society of Australasian Social Psychology, Bondi Beach, Australia.

Wheaton, A. (2001). Ostracism and susceptibility to the overtures of socially deviant groups and individuals. Unpublished master's thesis, Macquarie University, Sydney, Australia.

Williams, K. D. (1997). Social ostracism: The causes and consequences of "the silent treatment." In R. Kowalski (Ed.), Aversive interpersonal behaviors (pp. 133-170). New York: Plenum Publishing.

Williams, K. D. (2001). Ostracism: The power of silence. New York: Guilford Press.

Williams, K. D., Cheung, C. K. T., \& Choi, W. (2000). Cyberostracism: Effects of being ignored over the Internet. Journal of Personality and Social Psychology, 79, 748-762.

Williams, K. D., Govan, C. L., Croker, V., Tynan, D., Cruickshank, M., \& Lam, A. (2002). Investigations into differences between social- and cyberostracism. Group Dynamics, 6, 65-77.

Williams, K. D., \& Sommer, K. L. (1997). Social ostracism by one's coworkers: Does rejection lead to loafing or compensation? Personality and Social Psychology Bulletin, 23, 693-706.

Williams, K. D., \& Zadro, L. (in press). Ostracism: The indiscriminate early detection system. In K. D. Williams, J. P. Forgas, \& W. von Hippel (Eds.), The social outcast: Effects of ostracism, social exclusion, rejection, and bullying. New York: Psychology Press.

Wockner, C. (2002, July 17). Bash a Christian: Rapists' hi-tech message of hate. The Daily Telegraph, p. 3.

Yamaguchi, S. (1994). Collectivism among the Japanese: A perspective from the self. In U. Kim, H. C. Triandis, C. Kagitcibasi, S. C. Choi, \& G. Yoon (Ed.), Individualism and collectivism (pp. 175-188). Newbury Park, CA: Sage.

Zadro, L., Williams, K. D., \& Richardson, R. (2004). How low can you go? Ostracism by a computer lowers belonging, control, self-esteem, and meaningful existence. Journal of Experimental Social Psychology, 40, 560-567.

Received November 20, 2003 Revision received June 25, 2004 Accepted June 25, 2004 